\title{
Adult Nasoethmoidal Encephalocele Corrected by Supraorbitary Approach: Case Report and Literature Review
}

\section{Encefalocele nasoetmoidal de adulto corrigida por acesso supraorbitário: Relato de caso e revisão de literatura}

\author{
Francisco Fernando Dacier Teixeira ${ }^{1}$ Raysa Moreira Aprígio ${ }^{1}$ Dionei Freitas de Moraes ${ }^{1}$ \\ Mário José Góes ${ }^{1}$ Feres Chaddad-Neto ${ }^{2}$ Ricardo Lourenço Caramanti ${ }^{1}$ \\ Address for correspondence Ricardo L. Camaranti, MD, \\ Departamento de Neurocirurgia, Faculdade de Medicina de São José \\ do Rio Preto, São José do Rio Preto, SP, Brazil \\ (e-mail: ricardocaramanti1987@gmail.com).
}

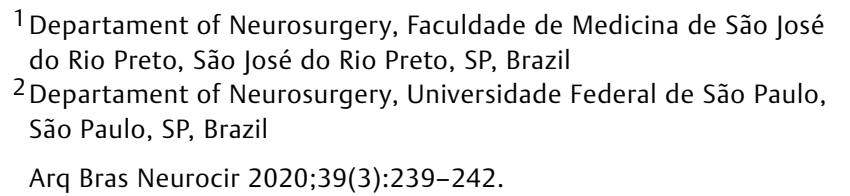

\begin{abstract}
Keywords

- encephalocele

- supraorbitary craniotomy

- nasal fluid leak

Resumo

Palavras-chave

- encefalocele

- craniotomia supraorbitária

- fístula liquórica nasal

Encephalocele is a protrusion of the central nervous system elements through a defect in the dura mater and in the cranium. The prevalence of encephalocele ranges from 0.08 to 0.5 per 1,000 births. The posterior encephaloceles are more common in North America and Europe, while frontal defect is frequently found in Asia. The present paper describes a 26-year-old male patient presenting with cerebrospinal fluid leak and meningitis symptoms. He was diagnosed with congenital nasoethmoidal encephalocele and treated surgically using a supraorbital approach without complications.

Encefalocele é definida como uma protrusão dos elementos do sistema nervoso central por um defeito localizado na dura máter no crânio. Sua prevalência apresenta-se entre 0.08 e 0.5 casos a cada 1.000 nascimentos. As encefaloceles posteriores são mais comuns na América do Norte e na Europa, já os defeitos frontais são frequentemente encontrados na Ásia. O presente artigo descreve o caso de um paciente do sexo masculino de 26 anos de idade com quadro de fístula liquórica nasal associada a meningite de repetição. Ele foi diagnosticado com encefalocele nasoetmoidal congênita, e tratado de forma cirúrgica com um acesso via supraorbital, sendo realizada a correção completa da falha sem intercorrências.
\end{abstract}

\section{Introduction}

Encephalocele is a type of cranial dysraphism that occurs as a protrusion of intracranial content through a defect in the cranial floor, thus leading to the formation of a herniary sac. Defects in the embryogenesis process, viral infections, hyperthermia, radiotherapy, hypervitaminosis, and the use of salicylates in early pregnancy have been implicated in its pathogenesis. ${ }^{1}$ The prevalence of encephalocele ranges

received

March 31, 2020

accepted

May 12, 2020
DOI https://doi.org/

10.1055/s-0040-1713919. ISSN 0103-5355. from 0.08 to 0.5 per 1,000 births. $^{2}$ Suwanwela et $\mathrm{al}^{3}$ classified encephaloceles based on the location and type of skull defect as occipital, basal and frontoethmoidal encephalocele. In frontoethmoidal encephalocele, a congenital disorder characterized by structural changes at the junction of the frontal and ethmoid bones, internally, and in the frontonaso-orbital region, externally, which results in facial disfigurement. It is further divided into three subtypes:
Copyright $\odot 2020$ by Thieme Revinter Publicações Ltda, Rio de Janeiro, Brazil
License terms

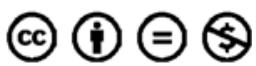


nasofrontal (NF), nasoethmoidal (NE), and naso-orbital (NO). ${ }^{3}$

Only $\sim 50 \%$ of fetuses with encephaloceles survive until birth. Most surviving infants with encephaloceles have cognitive deficits, and hydrocephalus, spasticity, and seizures are also common in these children. Up to half of these children have chromosomal abnormalities. ${ }^{2}$

Imaging exams, such as head tomography with thin slices of skull base or magnetic resonance, are indispensable to diagnoses. In some cases, confusion may occur, mainly when the skull defect is very small. ${ }^{4,5}$

The treatment of choice is surgery, which consists in repairing the skull base defect with or without resection of the herniary sac. Many endoscopic and open surgical approach techniques have been described in the literature with good results. ${ }^{6-9}$

The present case report describes a 26-year-old male patient with nasoethmoidal encephalocele corrected with a transcranial supraorbitary approach.

\section{Case Report}

A 26-years-old male patient was admitted in an emergency room with 2 days of headache, stiff neck, and fever. He reported a periodic fluid nasal secretion and 3 previous meningitis episodes in the past 3 years. Physical examination did not show any type of cranial abnormality, despite the presence of fluid leak. A liquor sample was collected whose result showed meningitis, and a head computed tomography $(\mathrm{CT})$ presented a skull base defect measuring $1.4 \times 0.6 \mathrm{~cm}$ with a large herniation sac with brain tissue from the ethmoidal bone to the nasal cavity measuring $3.6 \times 1.8 \times 1.3 \mathrm{~cm}$. After treatment of the central nervous system infection, the patient underwent a surgical correction of the skull base and excision of the intracranial herniary sac (-Fig. 1).

Due to a large skull base defect with more than $1 \mathrm{~cm}$, a supraorbital approach was performed, which provided a better exposition of bone defect and hernial sac with good aesthetic results. The dura-mater was dissected from the bone and herniary sac, and ethmoidal bone defects next to the cribriform plate were observed. The amputation of the intracranial herniary content was performed with primary duraplasty using first suture and, after, a dural substitute. The repair of the anterior skull base bone was made with bone cement (-Fig. 2 ).

The patient evolved without complications and was discharged after 4 days, no longer reporting CSF leak or any other symptoms. The postoperative head CT showed complete closure of the ethmoidal bone defect ( $\mathbf{- F i g . ~} \mathbf{3}$ ).

\section{Discussion}

Encephaloceles are more common in Southeast Asia, with a related incidence from 1:3,500 to 1:6,000 births. ${ }^{10}$ In Western countries, this pathology is rare, with an incidence of 1 to 40,000 births. ${ }^{11,12}$ In general, it is associated with others brain alterations, like corpus callosum agenesis, hydrocephalus, singles ventricle, Dandy-Walker malformation, ${ }^{13}$ microcephaly, epilepsy, ${ }^{14}$ cavum vergae, and arachnoid cyst. ${ }^{6}$ In our case, a central nervous system defect was not found.

The occipital encephaloceles are described as the most common type. ${ }^{14,15}$ However, the frontoethmoidal type is the most described in the literature; of these, nasoethmoidal is the most commonly found in studies. ${ }^{6,13,14,16}$

Mahatamarat et $\mathrm{al}^{7}$ classify frontoethmoidal encephalocele in some subtypes: nasofrontal, in which the defect is localized between the nasal and frontal bones; nasoorbital with herniation through the medial orbital wall; nasoethmoidal was characterized by hernial sac between the nasal bones and nasal cartilages; Combined nasoethmoidal and naso-orbital; and abortive, when the defect is unidentifiable. ${ }^{7}$

Many surgical techniques were described to correct meningoencephaloceles with an intracranial or an endoscopic approach. The endonasal endoscopic approach is preferred in smaller defects and cases without facial deformations or external tumor mass. The skull deformities reconstruction

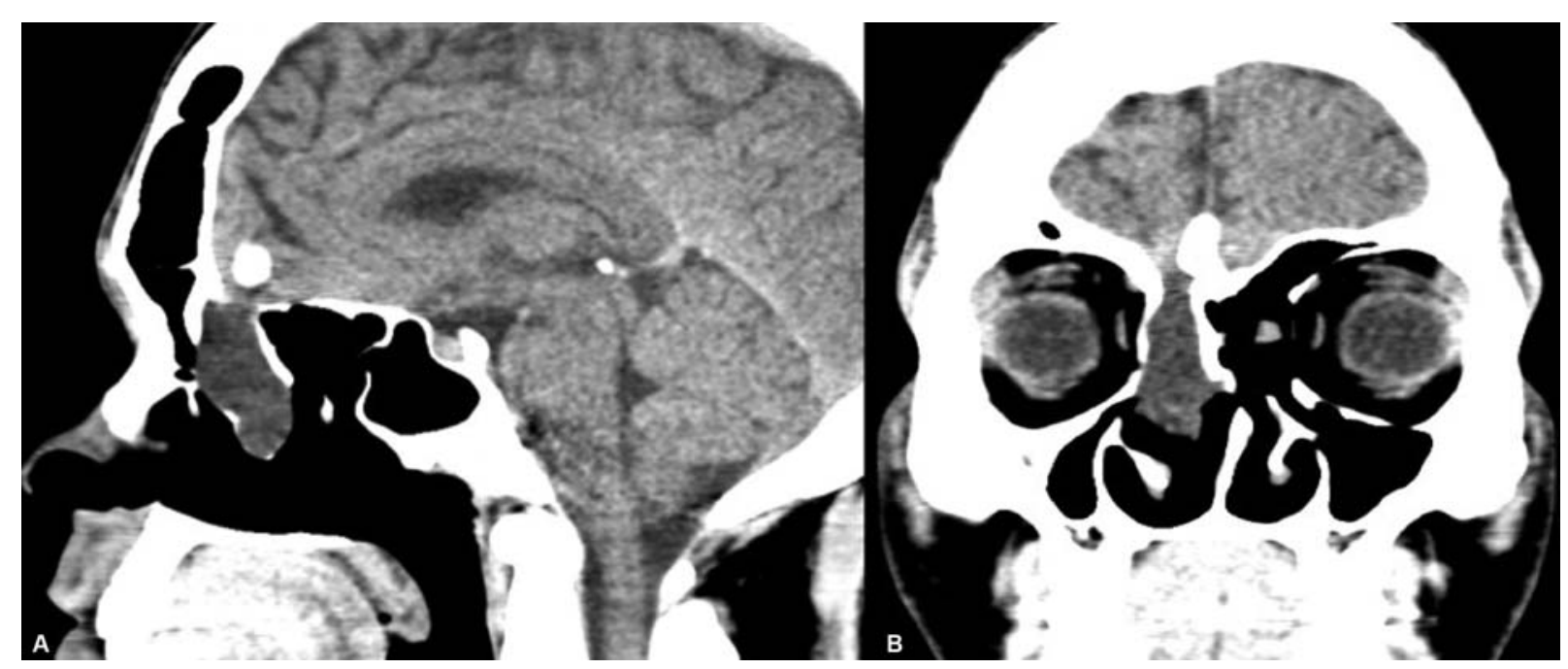

Fig. 1 A and B - Head computed tomography shown in sagittal and coronal sequences with an anterior skull base encephalocele with large bone defect connecting the intracranial anterior floor with the nasal region. 


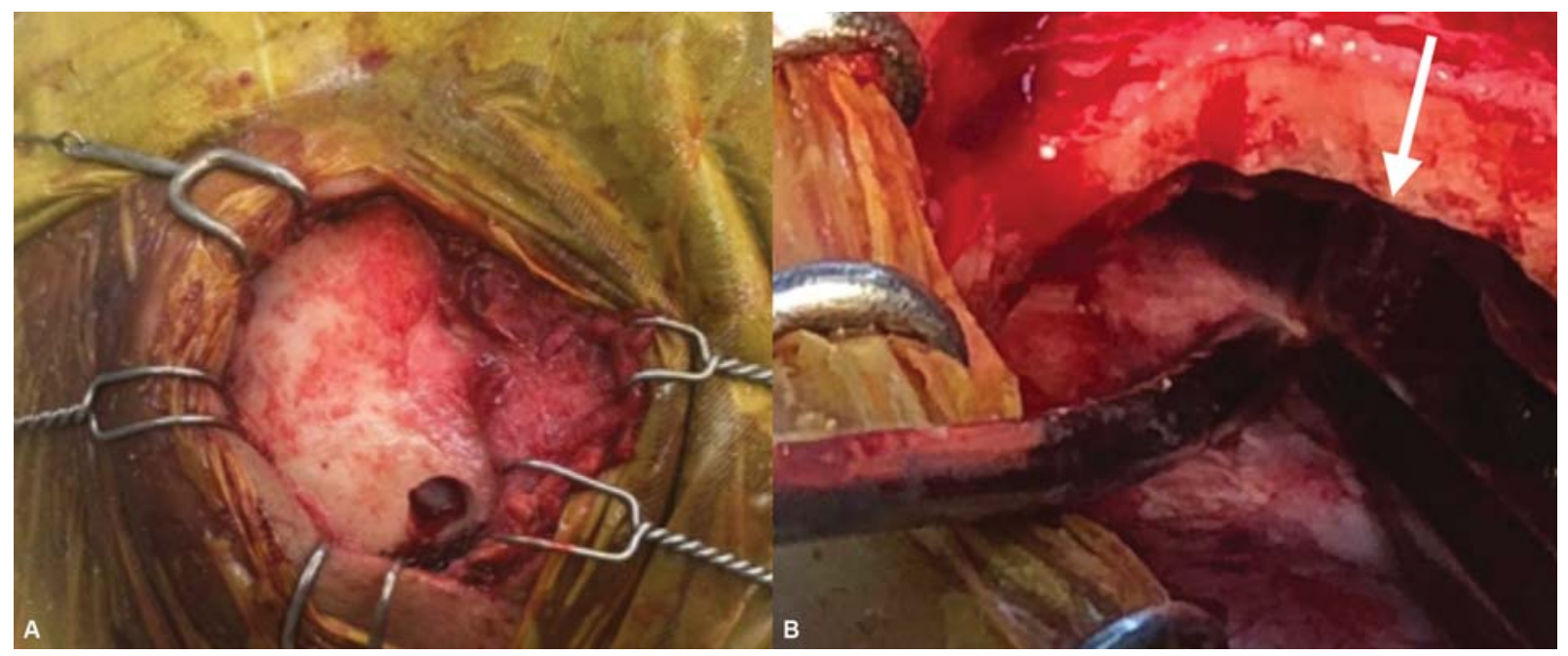

Fig. 2 A - Right supraorbital craniotomy with one burr hole. B - Anterior extradural space with encephalocele (white arrow) connecting the intracranial and nasal spaces.

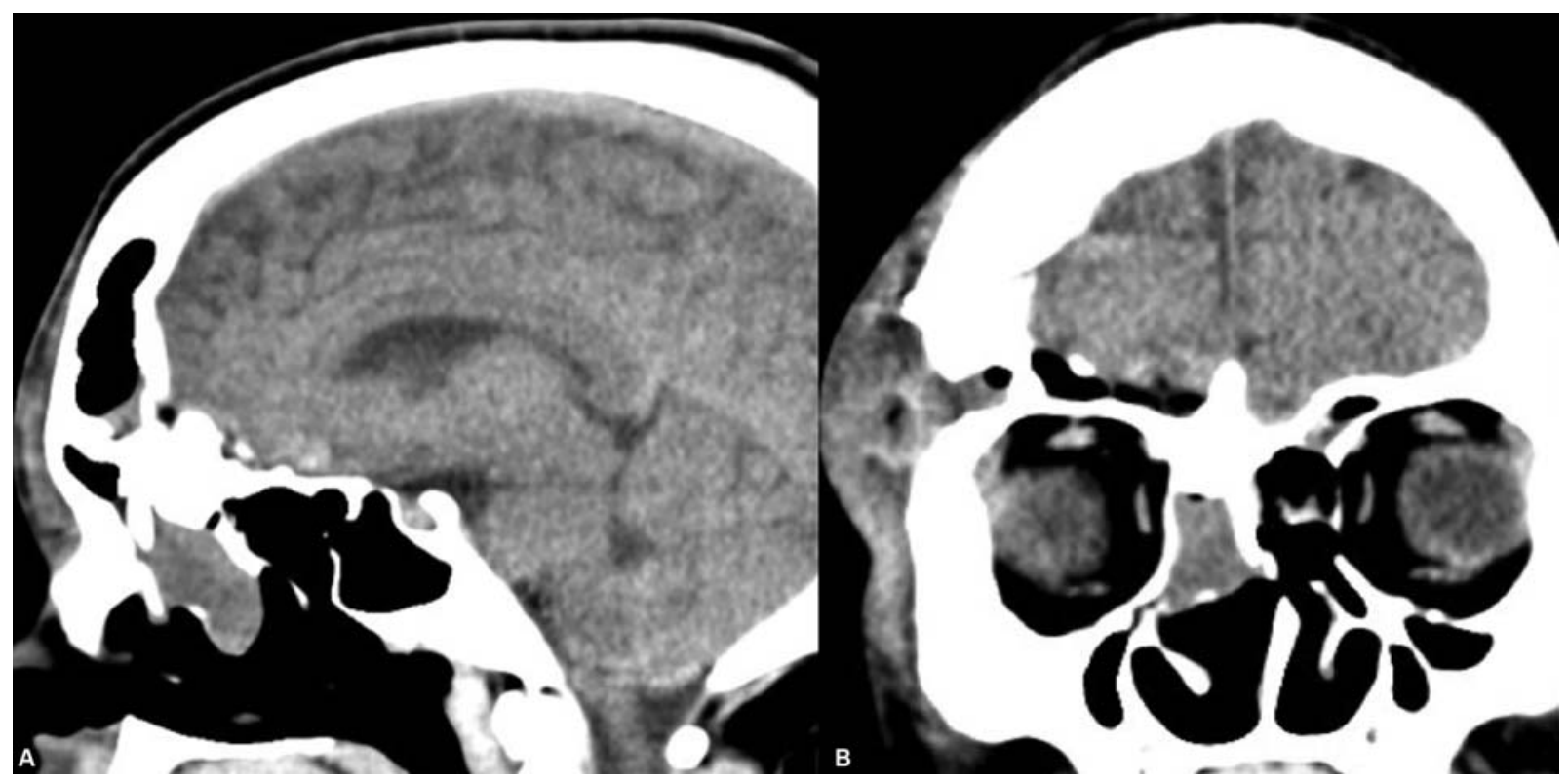

Fig. 3 A and B - Postoperative head computed tomography in sagittal and coronal sequences showing a complete correction of anterior fossa floor with bone cement and cerebrospinal fluid leak resolution.

can be performed with fat tissue, fibrin sealant, and dural substitute. ${ }^{9,17}$

Otherwise, transcranial approaches like the traditional Chula technique are preferred in cases with large or ectopic mass, which need some skin removal or recidivist case with previous scar face, but it leaves an inconvenient scar on the patient's face. ${ }^{6}$ Some authors described a modified Chula technique, made with no facial incision, using a bicoronal approach to the hernial sac, with correction of skull defect. Both techniques need a large traumatic T-shaped osteotomy in the medial portion of the superior orbital rim, upper medial orbital wall, and nasal bones. ${ }^{7}$ Bone cement has been described in the literature to treat bone defects of encephaloceles since 1959; however, it is nowadays reserved for large skull defects. ${ }^{18}$

The subfrontal craniotomy was a previous transcranial approach described to treat frontoethmoidal encephaloceles with good outcomes using bone grafts, periosteum, and graft of temporal fascia to close the skull defect. This type of approach makes it possible to perform the surgery in one stage, decreasing surgical risks. ${ }^{16,19}$

The amputation of the herniary sac in frontoethmoidal encephalocele is considered secure because the brain tissue inside is almost non-functional and only rarely epileptogenic. ${ }^{16}$

\section{Conclusion}

Adult encephalocele cases are rare and need to be investigated in patients with liquoric fistula without traumatic or iatrogenic history.

The supraorbitary approach should be considered to treat unilateral nasoethmoidal encephaloceles because it provides 
good exposition and has the advantage of being less traumatic with better aesthetic results.

\section{Conflict of Interests}

The authors declare that they have no conflict of interests.

\section{References}

1 Mahajan C, Rath GP, Bithal PK, Mahapatra AK. Perioperative Management of Children With Giant Encephalocele: A Clinical Report of 29 Cases. J Neurosurg Anesthesiol 2017;29(03):322-329

2 Gandhoke GS, Goldschmidt E, Kellogg R, Greene S. Encephalocele development from a congenital meningocele: case report. J Neurosurg Pediatr 2017;20(05):419-422

3 Suwanwela C, Suwanwela N. A morphological classification of sincipital encephalomeningoceles. J Neurosurg 1972;36(02):201-211

4 Suwanwela C, Hongsaprabhas C. Fronto-ethmoidal encephalomeningocele. J Neurosurg 1966;25(02):172-182

5 Santos-Franco JA, Dávila-Romero J, Rangel-Morales C, SandovalBalanzario M, Lee A. Obstrucción nasal crónica: encefalocele nasoetmoidal em paciente adulto. Gac Med Mex 2010;146(04):291-293

6 Arifin M, Suryaningtyas W, Bajamal AH. Frontoethmoidal encephalocele: clinical presentation, diagnosis, treatment, and complications in 400 cases. Childs Nerv Syst 2018;34(06):1161-1168

7 Mahatumarat C, Rojvachiranonda N, Taecholarn C. Frontoethmoidal encephalomeningocele: surgical correction by the Chula technique. Plast Reconstr Surg 2003;111(02):556-565, discussion 566-567

8 Rojvachiranonda N, David DJ, Moore MH, Cole J. Frontoethmoidal encephalomeningocele: new morphological findings and a new classification. J Craniofac Surg 2003;14(06):847-858

9 Zoghlami A, Bon Mardion N, Callonnec F, Dehesdin D, Proust F, Marie JP. Transalar transsphenoidal meningoencephalocele presenting in the form of recurrent meningitis: Report of two cases and discussion of the diagnosis and treatment. Eur Ann Otorhinolaryngol Head Neck Dis 2016;133(06):423-427

10 Hassanein AG, Fadle KN. Single-stage combined craniofacial repair for frontoethmoidal meningoencephalocele. J Craniofac Surg 2017;28(01):e9-e12

11 Smith DE, Murphy MJ, Hitchon PW, Babin RW, Abu-Yousef MM. Transsphenoidal encephaloceles. Surg Neurol 1983;20(06): 471-480

12 Donnenfeld AE, Hughes $\mathrm{H}$, Weiner S. Prenatal diagnosis and perinatal management of frontoethmoidal meningoencephalocele. Am J Perinatol 1988;5(01):51-53

13 Boonvisut S, Ladpli S, Sujatanond M, et al. Morphologic study of 120 skull base defects in frontoethmoidal encephalomeningoceles. Plast Reconstr Surg 1998;101(07):1784-1795

14 Leelanukrom R, Wacharasint P, Kaewanuchit A. Perioperative management for surgical correction of frontoethmoidal encephalomeningocele in children: a review of 102 cases. Paediatr Anaesth 2007;17(09):856-862

15 Warf BC, Stagno V, Mugamba J. Encephalocele in Uganda: ethnic distinctions in lesion location, endoscopic management of hydrocephalus, and survival in 110 consecutive children. J Neurosurg Pediatr 2011;7(01):88-93

16 Mahapatra AK, Suri A. Anterior encephaloceles: a study of 92 cases. Pediatr Neurosurg 2002;36(03):113-118

17 Gumussoy M, Ugur O, Cukurova I, Uluyol S. Recurrent meningitis and frontal encephalocele as delayed complications of craniofacial trauma. J Craniofac Surg 2014;25(02):529-530

18 Dodge HW Jr, Love JG, Kernohan JW. Intranasal encephalomeningoceles associated with cranium bifidum. AMA Arch Surg 1959;79(01):75-84

19 Gun R, Tosun F, Durmaz A, et al. Predictors of surgical approaches for the repair of anterior cranial base encephaloceles. Eur Arch Otorhinolaryngol 2013;270(04):1299-1305 